\title{
1. Introduction to International Commercial Arbitration
}

\section{INTRODUCTION}

Arbitration is a form of dispute resolution with a long history. ${ }^{1}$ From its first use in ancient times it has gradually evolved into a method of resolving disputes that is popular across nations, jurisdictions and legal traditions. ${ }^{2}$ But what exactly is arbitration and how does it differ from other forms of dispute resolution? What renders an arbitration 'commercial' and when is it 'international'? These questions are the focus of the present chapter.

\section{ARBITRATION}

There is no universally accepted definition of what constitutes arbitration. ${ }^{3}$ However, one can identify three elements that distinguish arbitration proceedings from other forms of dispute resolution. These elements are reflected in the normative framework on arbitration.

\section{A. The adjudicatory power is vested with arbitrators}

The first characteristic feature of arbitration is that the adjudicatory power is vested with arbitrators, that is, one or several individuals acting in their

1 Gary Born, International Arbitration: Cases and Materials (Kluwer 2015) 2 et seq.

2 Queen Mary 2015 International Arbitration Survey, Improvements and Innovations in International Arbitration, www.arbitration.qmul.ac.uk/media/ arbitration/docs/2015_International_Arbitration_Survey.pdf accessed 20 August 2020, 5.

3 See, e.g., Emmanuel E. Gaillard and John Savage, Fouchard Gaillard Goldman on International Commercial Arbitration (Kluwer 1999) 8; Jean-François Poudret and Sébastien Besson, Comparative Law on International Arbitration (2nd edn, Sweet and Maxwell 2007) 1; Gary Born, International Commercial Arbitration (3rd edn, Kluwer 2021) 269 et seq.; Julian D.M. Lew et al., Comparative International Commercial Arbitration (Kluwer 2003) 1; Tibor Várady, et al., International Commercial Arbitration: A Transnational Perspective (West Academic 2015) 2. 
private capacity. ${ }^{4}$ The private capacity in which these individuals are acting distinguishes them from judges who act in public capacity. ${ }^{5}$ Unlike judges, arbitrators are either selected by the parties or on behalf of the parties by an arbitral institution, an appointing authority or a State court. ${ }^{6}$

Even though the parties typically have participatory rights in the constitution of the arbitral tribunal, their powers are not unlimited. Most importantly, they cannot appoint partisan arbitrators. The normative framework on arbitration requires arbitrators to be neutral; as set forth in Chapter 4, most arbitration statutes impose obligations of independence and impartiality. ${ }^{7}$ Various mechanisms, including disclosure obligations for arbitrators and the possibility of challenging either an arbitrator's appointment or an arbitration award rendered by a biased arbitrator, are safeguards that ensure the arbitrators' impartiality and independence. ${ }^{8}$

By conferring adjudicatory power upon arbitrators, parties evidence their willingness to exclude their dispute from being subject to the decision-making authority of State courts. ${ }^{9}$ However, State courts may still exercise limited supervisory and supportive functions with regard to arbitration proceedings. ${ }^{10}$ As part of their supervisory functions, State courts may render decisions on the validity of an arbitration agreement, the challenge and appointment of arbitrators, the set-aside or the recognition and enforcement of an arbitral award, and so on. ${ }^{11}$ As part of their supportive functions, State courts may compel parties to arbitrate, grant interim relief or examine witnesses who refuse to appear before arbitral tribunals and enforce an ultimate arbitration award. ${ }^{12}$ Since the monopoly of power lies with the State and its organs, arbitral tribunals do not enjoy the independent coercive powers that are necessary to order the

4 See, e.g., Art. I (2) Convention on the Recognition and Enforcement of Foreign Arbitral Awards, 10 June 1958, 330 U.N.T.S. 4739 (hereinafter: 'New York Convention').

5 Margaret L. Moses, The Principles and Practice of International Commercial Arbitration (Cambridge University Press 2012) 2.

6 See, e.g., Arts. 6 and 11 UNCITRAL Model Law.

7 See, e.g., German Federal Court of Justice, 3 July 1975 (1976) Neue Juristische Wochenschrift 109; German Federal Court of Justice, 27 May 2004 (2004) SchiedsVZ 205; Poudret and Besson, supra n. 3, 5.

8 See, e.g., Arts. 12 and 13 UNCITRAL Model Law.

9 Tanning Research Laboratories, Inc. v Hawaiian Tropic de Venezuela C.A., Caracas Court of First Instance, 2 August 2006 and Venezuelan Supreme Court, 12 December 2006 in A.J. van den Berg (ed), Yearbook Commercial Arbitration 2008 (Vol. XXXIII) 1228-39.

${ }_{10}$ Ilias Bantekas, An Introduction to International Arbitration (Cambridge University Press 2015) 16.

11 See, e.g., Arts. 11, 13, 14, 16, 34, 35, 36 UNCITRAL Model Law.

12 See, e.g., Arts. 8, 17 J, 27, 35 UNCITRAL Model Law. 
appearance of witnesses against their will or to compel a party to abide by an arbitration award.

\section{B. Arbitrators are entitled to render a final, binding and enforceable decision}

The second distinguishing feature of arbitration lies in the fact that arbitrators are empowered to render a final, binding and enforceable decision, the 'arbitral award', in a judicial procedure. ${ }^{13}$

An arbitral award is a decision that finally resolves all or part of the dispute ${ }^{14}$ between the parties. ${ }^{15}$ It is binding in that it creates legal obligations for the parties to the dispute. ${ }^{16}$ Where a party fails to voluntarily comply with these obligations, an arbitral award may be enforced against the will of that party. ${ }^{17}$

Such enforcement requires the intervention of public authorities, since, as mentioned, only States enjoy a monopoly on the use of coercive power. States have undertaken obligations to recognize and enforce arbitral awards in various international agreements. Most prominently, the New York Convention on the Recognition and Enforcement of Foreign Arbitral Awards of 10 June 1958 (the 'New York Convention') sets forth obligations to recognize and enforce foreign arbitral awards in more than 160 States worldwide. ${ }^{18}$

13 Moses, supra n. 5, 2; Gaillard and Savage, supra n. 3, 11.

14 Art. I (1) New York Convention refers to 'differences' between natural or legal persons. As such, it refers to the requirement of a dispute. On the notion of the term 'dispute' see, e.g., Baltimar Aps. Ltd. v Nalder \& Biddle Ltd., Court of Appeal of New Zealand, 30 June 1994 in A.J. van den Berg (ed), Yearbook Commercial Arbitration 1995 (Vol. XX) 755-61; Jiangsu Hantong Ship Heavy Industry Co Ltd (PR China) v Sevan Holding I Pte Ltd, High Court, 29 December 2009 in A.J. van den Berg (ed), Yearbook Commercial Arbitration 2010 (Vol. XXXV) 438-9; John William Hayter $v$ Edward Ernest Nelson and another, Home Insurance Co., High Court of Justice, 22 March 1990 in A.J. van den Berg (ed), Yearbook Commercial Arbitration 1994 (Vol. XIX); Channel Tunnel Group Ltd. v France Manche S.A., Balfour Beatty Construction Ltd. and others, House of Lords, 21 January 1993 in A.J. van den Berg (ed), Yearbook Commercial Arbitration 1994 (Vol. XIX) 736-47.

15 German Federal Court of Justice, 24 July 2014 (2014) SchiedsVZ 303; Daum Global Holdings Corp. v Ybrant Digital Limited et al., US District Court, Southern District of New York, 20 February 2014 in A.J. van den Berg (ed), Yearbook Commercial Arbitration 2014 (Vol. XXXIX) 597-8.

16 Moses, supra n. 5, 1; Gaillard and Savage, supra n. 3, 11.

17 Jean Frydmann, David Frydmann and Anahold B.V. v Cosmair, Inc. and others, US District Court, Southern District of New York, 30 June 1995, 94 Civ. 3772 (LAP).

18 For the list of signatories, see www.uncitral.org/uncitral/en/uncitral_texts/ arbitration/NYConvention_status.html accessed 20 February 2021. Other conventions on the enforcement of arbitral awards include the Inter-American Convention on 
Arbitral awards must result from a procedure that is capable of respecting due process requirements. ${ }^{19}$ This proposition is certainly not unproblematic, because the failure to observe specific procedural guarantees constitutes a ground for refusal of recognition and enforcement under the New York Convention and does not necessarily put into question the status of a decision as an arbitral award altogether. However, one may counter this objection with the argument that the drafters of the New York Convention had in mind a dispute resolution mechanism that is capable of producing an award in compliance with the procedural guarantees reflected in the New York Convention.

An example may help to illustrate this point: under Article V (1) (b) of the New York Convention, an award can be refused recognition and enforcement if the arbitral tribunal did not respect the right to be heard of the parties. If the parties agree on a dispute resolution method that is incapable of ensuring the parties' right to be heard - such as tossing a coin - there is no need for separate proceedings on recognition and enforcement in which State courts verify whether the right to be heard has been complied with. The outcome of the proceedings simply does not qualify as an arbitral award, and this is irrespective of whether the outcome would be correct.

One need not only think of hypotheticals to prove that certain dispute resolution mechanisms do not qualify as arbitration. There is indeed case law supporting the proposition that a dispute resolution mechanism must provide for a procedure satisfying minimum rule of law requirements in order for its decision to qualify as an arbitral award. A 2004 decision of the German Federal Court of Justice may serve as an example. ${ }^{20}$ The decision arose from rather unusual facts: a member of a dog breeders' association had initiated proceedings before an 'arbitral tribunal' constituted on the basis of the association's bylaws. Having lost the proceedings, the applicant initiated set-aside proceedings against the 'arbitral award' that had been rendered by the 'arbitral tribunal' of the dog breeders' association.

The Federal Court of Justice held that the dispute resolution body did not qualify as a genuine arbitral tribunal. According to the Court, this followed from the fact that the tribunal was set up to resolve internal administrative disputes between members of the association's organs. The bylaws of the association neither ensured a fair and impartial procedure nor required that the decision be based on law or on principles of equity. Moreover, the parties did not have an equal opportunity to participate in the constitution of the arbitral

International Commercial Arbitration, adopted at Panama, 30 January 1975, U.N.T.S. No. 24384.

19 For a reference to the rule of law, see, e.g., German Federal Court of Justice, 11 October 2017 (2018) SchiedsVZ 271.

20 See German Federal Court of Justice, 27 May 2004 (2004) SchiedsVZ 205. 
tribunal. For these reasons, the Court held that the decision-making body did not qualify as an arbitral tribunal; neither did its decision constitute an arbitral award.

In light of the foregoing, there is much force in the argument that a minimum degree of due process must be guaranteed for a dispute resolution mechanism to be recognized as arbitration. ${ }^{21}$

\section{The adjudicatory power is based on the consensus of the parties}

The third characteristic of arbitration is that the adjudicatory power of arbitrators must be based on the agreement of the parties. ${ }^{22}$ Both the decision whether and the decision how to conduct arbitration proceedings are subject to party autonomy, which itself is subject to various limitations. ${ }^{23}$ By contrast, in most cases, at least one of the parties may not agree with the ultimate outcome of the arbitration proceedings. Exceptions include arbitral awards on agreed terms, which record a settlement reached by the parties during the arbitration proceedings. ${ }^{24}$ Unlike other settlement agreements, these offer the prospect of being enforceable under the New York Convention if the settlement is reached after the initiation of the arbitration proceedings. ${ }^{25}$

21 For a similar decision in the context of the enforcement of a domestic award, see German Federal Court of Justice, 11 October 2017 (2018) SchiedsVZ 271 (finding that members of a party's representative body are not eligible for the office as arbitrator and that a decision rendered by such a body does not qualify as arbitral award).

22 See Art. I (2) New York Convention, which refers to awards made by arbitrators or permanent arbitral bodies 'to which the parties have submitted'. See also Moses, supra n. 5, 2; Bantekas, supra n. 10, 4; Gaillard and Savage, supra n. 3, 28; see also Primary Industries (UK) Ltd. (UK) v Franchini Lamiere s.p.a., Banca Antoniana Popolare Veneta s.c.a.r.l., Italian Court of Cassation, 18 April 2003 in A.J. van den Berg (ed), Yearbook Commercial Arbitration 2004 (Vol. XXIX) 792-7 ('According to recent jurisprudence of the plenary session [of the Supreme Court] [...], an arbitral decision is an act of private autonomy issued by persons whose authority is based on the mission entrusted to them by the parties, rather than on ius imperii; hence, an award cannot be equated to a court decision').

23 Franco Ferrari, Limitations to Party Autonomy in International Commercial Arbitration (Juris Publishing 2016); Lew et al., supra n. 3, 4.

24 See, e.g., Art. 30 UNCITRAL Model Law, which provides: '(1) If, during arbitral proceedings, the parties settle the dispute, the arbitral tribunal shall terminate the proceedings and, if requested by the parties and not objected to by the arbitral tribunal, record the settlement in the form of an arbitral award on agreed terms. (2) An award on agreed terms shall be made in accordance with the provisions of article 31 and shall state it is an award. Such an award has the same status and effect as any other award on the merits of the case.' See also Born, supra n. 3, 3720.

25 When the New York Convention was created, this issue was raised by the drafters but not decided upon. See Travaux préparatoires, Recognition and Enforcement 
The decision by the parties as to whether to arbitrate is expressed in an arbitration agreement. The New York Convention defines the latter as an 'agreement in writing under which the parties undertake to submit to arbitration all or any differences which have arisen or which may arise between them in respect of a defined legal relationship, whether contractual or not, concerning a subject matter capable of settlement by arbitration' ${ }^{26}$

Where such arbitration agreement is contained in a contract, it is also referred to as an 'arbitration clause'. ${ }^{27}$ A typical arbitration clause might provide: 'All disputes arising out of or in connection with the present contract shall be finally settled under the Rules of Arbitration of the International Chamber of Commerce by one or more arbitrators appointed in accordance with the said Rules. ${ }^{28}$ As set forth in Chapter 2, it would be prudent for the parties also to specify the place and language of the arbitration and the law applicable to the merits.

The decision how to conduct arbitration proceedings can be determined in the arbitration agreement or in a separate agreement, including one reached during the course of the proceedings. ${ }^{29}$

\section{The distinction between institutional and ad hoc arbitration}

Arbitrators may act either in ad hoc or in institutional arbitration proceedings. Institutional arbitration proceedings are characterized by the involvement of an arbitral institution that administers the proceedings in accordance with a fixed

of Foreign Arbitral Awards, Report by the Secretary-General, Annex I, Comments by Governments, E/2822, at 7 (10); Travaux préparatoires, United Nations Conference on International Commercial Arbitration, Consideration of the Draft Convention on the Recognition and Enforcement of Foreign Arbitral Awards, E/CONF.26/L.26. See also Travaux préparatoires, United Nations Conference on International Commercial Arbitration, Activities of Inter-Governmental and Non-Governmental Organizations in the Field of International Commercial Arbitration, Consolidated Report by the Secretary-General, E/CONF.26/4, 26.

26 Art. II (1) New York Convention.

27 Art. II (2) New York Convention.

${ }_{28}$ This is the Standard Arbitration Clause of the International Chamber of Commerce (ICC); see https://iccwbo.org/dispute-resolution-services/arbitration/ arbitration-clause/ accessed 20 March 2021.

29 Gaillard and Savage, supra n. 3, 30 et seq. 
set of arbitration rules that is generally ${ }^{30}$ created by the institution itself. ${ }^{31}$ Arbitral institutions exercise various case management functions with regard to arbitration proceedings. ${ }^{32}$ Generally, they collect funds to cover the arbitrators' fees and expenses ${ }^{33}$ and monitor the efficient conduct of the proceedings. ${ }^{34}$ Beyond this, arbitral institutions may be involved in certain procedural decisions such as prima facie jurisdictional assessments, ${ }^{35}$ the appointment, confirmation or challenge of arbitrators, ${ }^{36}$ or the determination of the seat ${ }^{37}$ and the language of the arbitration. ${ }^{38}$ Some arbitral institutions also exercise a form of quality control of the arbitral award in a scrutiny process at the end of proceedings. ${ }^{39}$ For such services, arbitral institutions typically charge administrative fees. ${ }^{40}$ The administrative decisions of arbitral institutions do not qualify as arbitral awards. ${ }^{41}$

Ad hoc arbitration proceedings are not administered by arbitral institutions and therefore do not trigger any administrative fees. ${ }^{42}$ While ad hoc proceed-

30 For an exception see, e.g., Insigma Technology Co Ltd v Alstom Technology Ltd., 2 June 2009, [2009] 3 SLR 936; [2009] SGCA 24 (the arbitration clause read: 'Any and all such disputes shall be finally resolved by arbitration before the Singapore International Arbitration Centre in accordance with the Rules of Arbitration of the International Chamber of Commerce then in effect and the proceedings shall take place in Singapore and the official language shall be English').

31 Examples include the International Chamber of Commerce, the Permanent Court of Arbitration, the American Arbitration Association with its International Centre for Dispute Resolution, the London Court of International Arbitration, the Singapore International Arbitration Centre, the Hong Kong International Arbitration Centre, the Swiss Chambers of Commerce, the Stockholm Chamber of Commerce, the Vienna International Arbitral Centre, the Dubai International Arbitration Centre, the Kuala Lumpur Regional Centre for Arbitration, the German Institution of Arbitration and the Danish Institute of Arbitration.

32 Carita Wallgren-Lindholm, 'Ad hoc arbitration v. institutional arbitration' in G. Cordero Moss (ed), International Commercial Arbitration: Different Forms and their Features (Cambridge University Press 2013) 61, 63 et seq.

33 See, e.g., Art. 37 ICC Rules (2021).

34 See, e.g., Arts. 23, 24, 27, 31 ICC Rules (2021).

35 See, e.g., Art. 6 ICC Rules (2021).

36 See, e.g., Art. 13 ICC Rules (2021).

37 See, e.g., Art. 18 ICC Rules (2021).

38 See, e.g., Art. 20 ICC Rules (2021).

39 See, e.g., Art. 34 ICC Rules (2021).

40 See, e.g., Art. 38 ICC Rules (2021); see also Wallgren-Lindholm, supra n. 32, 68.

41 Marks 3-Zet-Ernst Marks GmbH \& Co. KG v Presstek Inc., US District Court, District of New Hampshire, 9 August 2005 in A.J. van den Berg (ed), Yearbook Commercial Arbitration 2006 (Vol. XXXI) 1256.

42 Lew et al., supra n. 3, 33. In some ad hoc arbitration proceedings, the parties nevertheless agree to pay an additional administrative fee to the chair of the arbitral tribunal. 
ings offer the benefit of a large degree of flexibility, ${ }^{43}$ the lack of institutional support goes hand in hand with greater responsibilities of the parties and the arbitrators with regard to the administration of the proceedings. ${ }^{44}$ There are various sets of arbitration rules that may guide parties and arbitrators alike in ad hoc arbitration proceedings. The UNCITRAL Arbitration Rules are a prominent example. They were adopted in 1976 and revised in 2010 and 2013. ${ }^{45}$

In both ad hoc and institutional arbitrations, the tribunal is typically formed for the individual matter to be decided. Against this background, the question arises what is meant by 'permanent arbitral bodies', which are equally referred to in Article I of the New York Convention. ${ }^{46}$ The preparatory works of the New York Convention help to answer this question. They show that the reference to permanent arbitral bodies was inserted at the request of the former Czechoslovakia and the former Soviet Union, which wanted to clarify that the New York Convention should also apply to awards rendered in institutional arbitration. ${ }^{47}$ The representative of Czechoslovakia referred to 'awards of the Court of Arbitration of the Czechoslovak Chamber of Commerce', while the Soviet representative referred to awards of the 'French Chamber of Commerce' as an example of a permanent arbitral body. ${ }^{48}$ While there were discussions as to whether this clarification was altogether necessary, the delegates ultimately decided to keep the reference to permanent arbitral bodies, emphasizing that it would only cover arbitrations based on consent. ${ }^{49}$ The drafting history therefore supports the proposition that the reference to permanent arbitral bodies

43 See Art. 1 (1) UNCITRAL Arbitration Rules (2010).

44 Born, supra n. 3, 189 et seq.

45 For further reference see Clyde Croft et al., A Guide to the UNCITRAL Arbitration Rules (Cambridge University Press 2013) 11 et seq.; see also Corrine Montineri, 'The UNCITRAL Arbitration Rules and their use in ad hoc arbitration' in Cordero Moss, supra n. 32, 82, 89 et seq.

46 Art. I New York Convention.

47 United Nations Conference on International Commercial Arbitration, 20 May-10 June 1958, Consideration of the Draft Convention on the Recognition and Enforcement of Foreign Arbitral Awards (Item 4 of the Agenda), Union of Soviet Socialist Republics: amendment to Art. I of the draft Convention, U.N. Doc. E/CONF.26/C1.L.2 (26 May 1958); United Nations Conference on International Commercial Arbitration, 20 May-10 June 1958, Consideration of the Draft Convention on the Recognition and Enforcement of Foreign Arbitral Awards (Item 4 of the Agenda), Czechoslovakia: amendment to the Draft Convention, U.N. Doc. E/CONF.26/L.10 (22 May 1958).

48 United Nations Conference on International Commercial Arbitration, 20 May-10 June 1958, Consideration of the Draft Convention on the Recognition of Foreign Arbitral Awards (E/2704 and Corr. 1; E/Conf.26/L.10), UN Doc. E/Conf.26/SR.8, p. 4 and 5 .

49 Id., p. 2-8. 
was not intended to create an exception from the principle of party autonomy. Specifically, it should not cover any courts of compulsory jurisdiction. ${ }^{50}$

One institution whose characterization as a permanent arbitral body has remained controversial is the Iran-United States Claims Tribunal. This institution was created in 1981 after the hostage crisis between the United States of America and the Islamic Republic of Iran to resolve certain claims by nationals of one State Party against the other State Party, as well as certain claims between the two State Parties. ${ }^{51}$ Some courts have considered the Iran-United States Claims Tribunal to be a permanent arbitral body and enforced its awards under the New York Convention. ${ }^{52}$ Other courts have indicated that a decision of the Iran-United States Claims Tribunal did not fall within the scope of the New York Convention. The English High Court, for example, did so in an obiter dictum in Mark Dallal v Bank Mellat. ${ }^{53}$ However, the English High Court grounded its decision on the absence of a written submission agreement - a requirement that will be analysed at a later stage in Chapter 2.

\section{E. The legal framework governing arbitration proceedings}

The delegation of adjudicatory powers to arbitrators in an arbitration agreement would have no consequences but for the existence of a legal framework that enforces that arbitration agreement, supports the arbitration proceedings and enforces the product of those proceedings - a final award. ${ }^{54}$ Otherwise, an agreement to arbitrate would be as useless as an agreement to toss a coin.

One important source of the legal framework governing arbitration proceedings is the so-called lex arbitri, which translates as 'arbitration law'. The applicable lex arbitri is determined by the place of arbitration (also referred to as

$50 \quad I d .$, p. 2.

51 Declaration of the Government of the Democratic and Popular Republic of Algeria Concerning the Settlement of Claims by the Government of the United States of America and the Government of the Islamic Republic of Iran of 19 January 1981 [hereinafter: 'Claims Settlement Declaration'] (1981) 75 American Journal of International Law 418.

52 Ministry of Def. of the Islamic Republic of Iran v Gould Inc., 23 October 1989, 887 F.2d 1357 (9th Cir. 1989).

${ }_{53}$ Mark Dallal v Bank Mellat, High Court, 26 July 1985 in A.J. van den Berg (ed), Yearbook Commercial Arbitration 1986 (Vol. XI) 547.

54 See Coppée Lavalin NV v Ken-Ren Fertilisers and Chemicals, 5 May 1994, (1994) 170 N.R. 203 (HL) ('On the one hand, the concept of arbitration as a consensual process reinforced by the ideas of transnationalism leans against the involvement of [...] a municipal court. On the other side there is the plain fact, palatable or not, that it is only a Court possessing coercive powers which could rescue the arbitration if it is in danger of foundering'). 
the 'seat of arbitration'), which creates a juridical link between an arbitration proceeding and the applicable arbitration law. ${ }^{55}$ For example, if parties select Paris as the place of arbitration, this triggers the application of the French arbitration law. As a consequence, the French courts will be responsible for exercising supervisory and supportive functions in respect of the arbitration proceedings and the French arbitration law will govern certain aspects of the arbitral procedure. In the absence of a choice by the parties, the seat can be identified by the arbitral tribunal, an arbitral institution or a court (in cases of ad hoc arbitrations).

While every State is responsible for creating its own arbitration law, many States have implemented the so-called UNCITRAL Model Law on International Commercial Arbitration ('UNCITRAL Model Law'), a non-binding instrument created with the goal of harmonizing arbitration laws. ${ }^{56}$ It was created by the United Nations Commission on International Trade Law ('UNCITRAL'). UNCITRAL was established by United Nations General Assembly Resolution 2205 (XXI) with the mandate to promote the progressive harmonization and unification of the law of international trade. ${ }^{57}$ The UNCITRAL Model Law forms the basis for legislation adopted in approximately 90 jurisdictions ${ }^{58}$ It contains fundamental provisions governing the arbitration procedure, ranging from the arbitration agreement to the grounds for set-aside of arbitral awards.

While arbitration laws form a framework for the conduct of an arbitration proceeding and can sometimes be a source of the procedures that govern those proceedings, typically the majority of the procedures that govern an arbitration proceeding are agreed to by the Parties. Parties typically reach agreement on the procedures that govern the conduct of their arbitration proceedings before any dispute arises. Thus, when parties enter into a contract - for example, a distribution agreement - they may agree at the time of that agreement to resolve any disputes arising out of it by arbitration. They reflect this by including an arbitration clause in their agreement, agreeing to arbitrate either on an ad hoc basis or by selecting a pre-existing set of arbitration rules. The arbitration clause quoted in section $\mathrm{C}$ reflects the selection of a pre-existing set of rules, the Rules of Arbitration of the International Chamber of Commerce.

\footnotetext{
55 Born, supra n. 3, 371 et seq.; Bantekas, supra n. 10, 13.

56 General Assembly Resolution 40/72 (11 December 1985). See also Marianne Roth, 'UNCITRAL Model Law on International Commercial Arbitration' in F.B. Weigand (ed), Practitioner's Handbook on International Commercial Arbitration (2nd edn, Oxford University Press 2009) 953, 957.

57 General Assembly Resolution 2205 (XXI), Establishment of the United Nations Commission on International Trade Law of 17 December 1966.

58 UNCITRAL 2012 Digest of Case Law on the Model Law on International Commercial Arbitration, 2012, 1.
} 
Absent such agreement and mandatory rules of procedure, arbitral tribunals can take decisions based on their discretion. The interplay of these different sources becomes clearer if one looks, for example, at the rules governing the receipt of written communications. In this respect, Article 3 of the UNCITRAL Model Law sets forth a default rule that applies ' $[u] n l e s s$ otherwise agreed by the parties'. By agreeing on the UNCITRAL Arbitration Rules (which are not to be confused with the UNCITRAL Model Law) ${ }^{59}$ the parties accept the more detailed rules on the receipt of written communications as contained therein. ${ }^{60}$ However, the parties can decide to further modify these provisions by means of an additional party agreement on this procedural issue. ${ }^{61}$ Absent such party agreement, the arbitral tribunal may give additional directions in a procedural order based on its discretion to conduct the proceedings as appropriate. ${ }^{62}$

The aforementioned sources are complemented by international conventions. Most prominently, the New York Convention contains an obligation to recognize arbitration agreements and to recognize and enforce arbitral awards. The details of how this Convention operates in practice will be examined in Chapters 10 and 11 of this book.

\section{F. Arbitration in comparison with other forms of dispute resolution}

The above-mentioned elements allow arbitration proceedings to be distinguished from other forms of dispute resolution.

Litigation differs from arbitration in that one or several judges who enjoy adjudicatory powers derived from statute render a judgment. ${ }^{63}$ The decision-making body and the source of adjudicatory powers are not the same as in arbitration proceedings. Judges may also possess coercive powers, which arbitral tribunals may not have for the reasons set forth above. The outcome of litigation proceedings is a court judgment which may be appealed before it

59 Unlike the UNCITRAL Model Law, which is addressed at States and guides them in designing their arbitration laws, the UNCITRAL Arbitration Rules are addressed at the parties and arbitral tribunals. Where agreed upon, they create a binding set of rules on how the arbitration proceedings are to be conducted. Croft et al., supra n. 45,12 et seq.

${ }^{60}$ Art. 2 UNCITRAL Arbitration Rules (2010).

61 Art. 1 UNCITRAL Arbitration Rules (2010); where parties have agreed that disputes between them in respect of a defined legal relationship, whether contractual or not, shall be referred to arbitration under the UNCITRAL Arbitration Rules, then such disputes shall be settled in accordance with these Rules subject to such modification as the parties may agree.

${ }_{62}$ Art. 17 UNCITRAL Arbitration Rules (2010).

63 Poudret and Besson, supra n. 3, 10. 
becomes final and enforceable. Despite the recent creation of the Convention of 2 July 2019 on the Recognition and Enforcement of Foreign Judgments in Civil or Commercial Matters (the 'Hague Judgments Convention'), which is supposed to become the equivalent of the New York Convention for court decisions, judgments are currently more difficult to enforce internationally than arbitral awards.

At times, parties may enter into a forum selection agreement, whereby they confer jurisdiction on a court that may otherwise lack jurisdiction. ${ }^{64}$ Still, this is not equivalent to an arbitration agreement, as the decision-making body remains a public body with adjudicatory powers derived from statute.

Arbitration can also be distinguished from negotiation. Negotiation, as its name suggests, is a form of dispute resolution by which the parties seek to resolve a dispute through discussion. ${ }^{65}$ The conduct of any negotiation and whether it is successful in resolving a dispute depends on the will of the parties. Unlike in arbitration proceedings, however, there is no neutral intermediary who enjoys any adjudicatory powers. Moreover, any settlement reached in negotiations may only become binding as a matter of contract law but is not otherwise enforceable.

Mediation and conciliation are forms of alternative dispute resolution where a neutral intermediary assists the parties in the resolution of their dispute. ${ }^{66}$ Mediators and conciliators help parties to find an amicable settlement of disputes by focusing on their respective interests ${ }^{67}$ This differs from arbitration proceedings in that this solution is not the product of an adjudicatory process and may not be imposed on the parties. ${ }^{68}$ While the terms 'mediation' and 'conciliation' are often used interchangeably, ${ }^{69}$ conciliators have historically assumed a more active role in making proposals for the resolution of the dispute than mediators. ${ }^{70}$ A successful mediation can result in a settlement agreement between the parties, which is binding but not enforceable. With

64 Poudret and Besson, supra n. 3, 10; Born, supra n. 3, 266 et seq.

65 Lew et al., supra n. 3, 13.

66 Moses, supra n. 5, 14; Bantekas, supra n. 10, 8.

67 Nigel Blackaby et al., Redfern and Hunter on International Arbitration (5th edn, Oxford University Press 2009) 46; Lew et al., supra n. 3, 12.

68 Gaillard and Savage, supra n. 3, 12.

69 Moses, supra n. 5, 15. See also Art. 1 (3) UNCITRAL Model Law on Conciliation, which defines conciliation as 'a process, whether referred to by the expression conciliation, mediation or an expression of similar import, whereby parties request a third person or persons ('the conciliator') to assist them in their attempt to reach an amicable settlement of their dispute arising out of or relating to a contractual or other legal relationship. The conciliator does not have the authority to impose upon the parties a solution to the dispute'.

70 Blackaby et al., supra n. 67, 47. 
the entry into force of the United Nations Convention on International Settlement Agreements Resulting from Mediation (the 'Singapore Convention on Mediation'), certain settlement agreements resulting from mediation will become enforceable under the terms set forth therein.

An expert determination is a referral of narrow issues to an independent intermediary with expertise in a specific field. ${ }^{71}$ The expert is not required to render a decision on a broader dispute. ${ }^{72}$ Instead, he or she typically decides on a narrow question, for example a matter of damage valuation or a technical issue. $^{73}$ The decision is not rendered in an adjudicatory procedure comparable to that of arbitration proceedings. ${ }^{74}$ The decision is normally binding as a matter of contract or procedural law, but not enforceable as an award. ${ }^{75}$

Various other forms of dispute resolution are also used in practice. ${ }^{76} \mathrm{With}$ the help of the above-mentioned criteria, they may be distinguished from arbitration proceedings.

\section{G. Advantages and disadvantages of arbitration}

The above observations on the different forms of dispute resolution give cause to reflect on the advantages and disadvantages of arbitration. The answer to this question certainly depends on various circumstances and it is hard to make a one-size-fits-all assessment. However, one can identify a number of factors that the users of arbitration may wish to consider when choosing the dispute resolution mechanism most appropriate to their (potential) dispute.

\section{i. Advantages}

One of the key advantages of arbitration is the enforceability of arbitral awards. Due to instruments such as the New York Convention, arbitral awards can be recognized and enforced virtually across the globe. As set forth above, no similarly effective enforcement mechanisms exist for the decisions rendered in other forms of dispute resolution. This may change with the entry into force of instruments such as the Hague Judgments Convention or the Singapore Convention on Mediation.

\footnotetext{
71 Várady et al., International Commercial Arbitration: A Transnational Perspective (West Academic Publishing 2015) 14; Lew et al., supra n. 3, 10.

72 Born, supra n. 3, 284.

3 Lew et al., supra n. 3, 10.

74 Jean Frydmann, David Frydmann and Anahold B.V. v Cosmair, Inc. and others, US District Court, Southern District of New York, 30 June 1995, 94 Civ. 3772 (LAP).

75 Blackaby et al., supra n. 67, 49; Poudret and Besson, supra n. 3, 14.

76 Lew et al., supra n. 3, 9 et seq.
} 
Another key feature and advantage of arbitration is the possibility to avoid having a dispute resolved in a particular legal system or national court. Parties may have a legitimate interest in avoiding certain legal systems and courts and opting instead for arbitration before a neutral panel of expert arbitrators. Leaving aside the risk of corruption, which exists in certain systems, ${ }^{77}$ access to justice may in certain jurisdictions create significant costs. This may include the need to appoint local counsel, become familiar with local practices, incur high translation costs, and so on. In arbitration proceedings, in contrast, parties may not be required to invest as many resources to familiarize themselves with local procedural rules. This is because the framework for international arbitration is to a considerable extent harmonized or even uniform. Moreover, arbitration proceedings are often conducted in a more efficient way and take less time than court proceedings.

A closely related distinguishing feature of arbitration is the parties' flexibility to tailor the procedures of the arbitration to their particular dispute. ${ }^{78}$ Being a form of dispute resolution that rests to a considerable degree on party autonomy, arbitration allows parties to design a dispute resolution mechanism that best suits their specific needs. Parties may reach agreement on a wide panoply of different issues ranging from the venue of the hearing to the number of written submissions and the language of the proceedings. The parties' freedom only finds limits in certain mandatory norms such as key guarantees of due process, restrictions on the subject matters that are capable of being resolved by arbitration, public policy, and so on. As such, the degree of party autonomy considerably exceeds that applicable in judicial proceedings.

The parties' ability to participate in the constitution of the arbitral tribunal is a further advantage of arbitration. It not only allows the parties to select an

77 According to Transparency International's Global Corruption Report 2007, '[c]orruption is undermining justice in many parts of the world, denying victims and the accused the basic right to a fair and impartial trial': https://issuu.com/transp arencyinternational/docs/global_corruption_report_2007_english?mode=window\& backgroundColor $=\% 23222222$, xxi accessed 18 March 2021 .

78 US courts point to this as an advantage of choosing to arbitrate under the United States Federal Arbitration Act (FAA); see, e.g., Univ. of Notre Dame (USA) in England v TJAC Waterloo, LLC, 28 June 2017, 861 F.3d 287, 291 (1st Cir. 2017) ('the Federal Arbitration Act "lets parties tailor some, even many, features of arbitration by contract, including [...] procedure"') (quoting Hall Street Assocs., L.L.C. v Mattel, Inc., 29 May 2007, 552 U.S. 576, 586, 128 S.Ct. 1396, 170 L.Ed.2d 254 (2008) (internal citation omitted)); Life Recei. Trust v Syndicate 102, 25 November 2008, 549 F.3d 210, 217 (2d Cir. 2008) (same); Salt Lake Tribune v Management Planning, 30 November 2004, 390 F.3d 684, 690 (10th Cir. 2004) ('Parties need not establish quasi-judicial proceedings resolving their disputes to gain the protections of the FAA, but may choose from a broad range of procedures and tailor arbitration to suit their peculiar circumstances'). 
arbitrator with the required expertise to adjudicate the given dispute. It also allows the parties to avoid arbitrators that may have a negative bias vis-à-vis parties from their home country.

Arbitration proceedings also offer the benefit of privacy and confidentiality. Privacy means that the public does not have access to the arbitration hearings and the materials and information exchanged during the arbitration proceedings: the public may not get access to briefs, attend the hearings, and so on, unless the parties agree otherwise or the applicable rules so allow. This is in contrast to court proceedings in some countries, where, barring a court order to the contrary, the public may have a right of access to court proceedings and to court filings. Confidentiality, in turn, refers to the obligation of those who have had access to information not to disclose it to third parties. The question of whether or not such confidentiality obligations exist depends on the applicable arbitration law, arbitration rules, party agreement or an order by the arbitral tribunal.

While one could certainly continue to list other advantages, arbitration also has various disadvantages.

\section{ii. Disadvantages}

To begin with, arbitrations may trigger significant costs. The main cost factors include the parties' legal costs, the fees and expenses of the arbitrators and the administrative fees of the arbitral institution in institutional arbitration. The largest portion of these costs is made up by the parties' legal costs. An ICC statistic of 2015 suggests that these legal costs may amount to more than 80 per cent of the overall costs. ${ }^{79}$ While one may speculate that similarly high costs might also accrue in complex court proceedings - even more so considering the multiple tiers of court proceedings - these costs may be prohibitive for smaller and medium-sized companies. Arbitral institutions have therefore rightly taken various initiatives to control costs of arbitration proceedings. ${ }^{80}$ They have taken similar initiatives to reduce the time of arbitration proceedings.

Another shortcoming of arbitration follows from its consent-based foundation: there are limitations to the parties' ability to join third parties to the arbitration proceedings. Courts can have jurisdiction over parties independent of their consent. Such jurisdiction is based on State constitutions and laws defining the circumstances in which a State court has jurisdiction over

79 ICC Commission Report, 'Decisions on Costs in International Arbitration' (2015) ICC Dispute Resolution Bulletin, Issue 2, 3.

${ }_{80}$ See, e.g., ICC Arbitration Commission Report on Techniques for Controlling Time and Costs in Arbitration, https://iccwbo.org/publication/icc-arbitration -commission-report-on-techniques-for-controlling-time-and-costs-in-arbitration/ accessed 21 March 2021. 
a person or entity (personal jurisdiction) and over a particular subject-matter (subject-matter jurisdiction). In court proceedings, therefore, it can be possible to join a third party to a lawsuit by giving a third party notice. For example, in a construction dispute between a contractor and an employer, a subcontractor may be given a third party notice and thereby compelled to participate in the proceedings. In a subsequent litigation between the contractor and the subcontractor, the subcontractor cannot successfully argue that the legal dispute between the contractor and the employer was decided incorrectly. No similar mechanism exists in arbitration proceedings.

The lack of coercive powers by arbitrators may be perceived as another disadvantage of arbitration. Unlike a State court that may coerce a recalcitrant witness to appear against his or her volition or issue an order of interim relief that can be directly enforced, arbitral tribunals do not have such powers. Rather, they are dependent on assistance by State courts. While courts in many jurisdictions are arbitration-friendly, some courts are not and may interfere with arbitration proceedings.

Beyond this, some of the advantages of arbitration have been criticized. For example, the privacy of arbitration proceedings may entail a lack of transparency and impede endeavours to create an elaborate body of case law. Likewise, the finality of arbitral decisions has a flipside, which is the lack of an appeals mechanism to review an arbitral decision.

In conclusion, the decision to arbitrate requires a careful analysis of the advantages and disadvantages of this form of dispute resolution. With these observations in mind, we will proceed by examining what renders an arbitration 'commercial' and how 'international' arbitration differs from domestic arbitration.

\section{COMMERCIAL}

In practice, the reference to 'commercial' arbitration is often used to distinguish a given type of arbitration from 'investment' arbitration. The latter is a form of arbitration which allows private investors to assert claims against foreign States that have interfered with foreign investments through unlawful sovereign acts. ${ }^{81}$ Most arbitration proceedings that are not 'investment' arbitration proceedings qualify as 'commercial' arbitrations under this approach. In legal terms, however, the distinction is more subtle. If one looks at the legal

81 On investment arbitration see, e.g., Campbell McLachlan et al., International Investment Arbitration: Substantive Principles (2nd edn, Oxford University Press 2017); Franco Ferrari and Brian King (eds), International Investment Arbitration in a nutshell (West Academic Publishing 2019). 
framework governing arbitration proceedings one can observe that a number of instruments are limited to 'commercial' arbitrations or 'commercial' disputes. For example, the UNCITRAL Model Law was designed for 'commercial' arbitrations. ${ }^{82}$ Footnote 2 of the UNCITRAL Model Law makes clear that:

[t]he term 'commercial' should be given a wide interpretation so as to cover matters arising from all relationships of a commercial nature, whether contractual or not. Relationships of a commercial nature include, but are not limited to, the following transactions: any trade transaction for the supply or exchange of goods or services; distribution agreement; commercial representation or agency; factoring; leasing; construction of works; consulting; engineering; licensing; investment; financing; banking; insurance; exploitation agreement or concession; joint venture and other forms of industrial or business cooperation; carriage of goods or passengers by air, sea, rail or road.

This wording shows that the drafters intended to ensure the application of the UNCITRAL Model Law to a large number of disputes. ${ }^{83}$ Various courts have adopted a broad interpretation of the term 'commercial' arbitration, ${ }^{84}$ which is in line with the intention of the drafters of the UNCITRAL Model Law. In certain jurisdictions, the interpretive clarification contained in footnote 2 to the UNCITRAL Model Law was even incorporated into the respective arbitration laws. ${ }^{85}$ In other jurisdictions, the UNCITRAL Model Law was implemented without any restriction to commercial arbitrations at all. ${ }^{86}$ Countries whose arbitration laws are not based on the UNCITRAL Model Law but also require arbitrations to be 'commercial' often favour a broad interpretation of the term as well. ${ }^{87}$

82 Art. 1 (1) UNCITRAL Model Law.

83 Lew et al., supra n. 3, 52; Peter Binder, International Commercial Arbitration and Conciliation in UNCITRAL Model Law Jurisdictions (2nd edn, Kluwer 2005) 18 et seq.

84 See, e.g., The United Mexican States v Metalclad Corp., Supreme Court of British Columbia, 2 May 2001; Re Carter et al. and McLaughlin et al., Ontario Court, 1 February 1996; R.M. Investments \& Trading Co. Pvt. Ltd. v Boeing Co., Supreme Court of India, 10 February 1994, 1994 AIR 1136, 1994 SCC (4) 541; Comed Chemicals Limited v C.N. Ramchand, Supreme Court of India, 6 November 2008, A.I.R. 2009 S.C. 494.

85 See, e.g., Art. 1 (6) British Columbia International Commercial Arbitration Act 1986; Art. 1 (2) Bulgarian Law on International Commercial Arbitration 2001.

86 Lew et al., supra n. 3, 53.

87 See, e.g., Société Kuwait Foreign Trading Contracting \& Investment v Société Icori Estero S.p.A., Paris Court of Appeals, 13 June 1996, Other courts have held that a dispute may not qualify as 'commercial' if it involves a State actor; see, e.g., Milantic Trans. S.A. v Ministerio de Producción de la Provincia de Buenos Aires, Astillero Río Santiago, La Plata Court of Appeals, 30 August 2007 in A.J. van den Berg (ed), 
Similar observations can be made if one looks at the New York Convention. According to its Article I para. 3, Contracting States may declare that the Convention shall apply 'only to differences arising out of legal relationships, whether contractual or not, which are considered as commercial under the national law of the State making such declaration' ${ }^{88}$ As will be explained in Chapter 10, many courts have interpreted the notion of 'commerciality' under the New York Convention broadly.

\section{INTERNATIONAL}

The distinction between 'international' and 'domestic' arbitration reflects the fact that the framework for arbitration proceedings involving an element of internationality is often different from the framework for purely domestic arbitrations.

National arbitration laws may provide different rules for international and domestic arbitration proceedings. An example is the French Code of Civil Procedure, which has a separate chapter for international arbitration proceedings. Article 1492 of the French Code of Civil Procedure provides that an arbitration proceeding is international if it "concerns interests of international trade'. ${ }^{89}$ French courts have taken a liberal approach in interpreting this requirement. ${ }^{90}$ According to French case law, it suffices that an arbitration concerns a transaction with cross-border elements. ${ }^{91}$ Where a transaction does not meet this requirement, parties may still conduct arbitration proceedings but some of the applicable provisions are different, as they are contained in the chapter on domestic arbitration proceedings. ${ }^{92}$

Other arbitration laws define internationality on the basis of a more subjective element, relating to the parties to the arbitration. The Swiss arbitration law, for example, contains a chapter on international arbitration which applies 'if, at the time of the conclusion of the arbitration agreement, at least one of the parties has neither its domicile nor its habitual residence in Switzerland' ${ }^{93}$

Yearbook Commercial Arbitration 2008 (Vol. XXXIII) 327-30 (regarding a contract entered into by a Province of Buenos Aires).

88 Art. I (3) New York Convention.

89 Art. 1492 French Code of Civil Procedure, www.legifrance.gouv.fr/Traductions/ en-English/Legifrance-translations accessed 18 March 2021.

90 Lew et al., supra n. 3, 58 et seq.; see also Carthago Films Sarl v Babel Sarl, Paris Court of Appeals, 29 March 2001.

91 Ibid.

92 See Arts. 1442-1491 French Code of Civil Procedure, www.legifrance.gouv.fr/ Traductions/en-English/Legifrance-translations accessed 18 March 2021.

93 Art. 176 Federal Statute on Private International Law, https://www .swissarbitration.org/files/34/Swiss\%20International\%20Arbitration\%20Law/IPRG _english.pdf accessed 18 March 2021. 
In a similar vein, the Belgian arbitration law makes a distinction between international and domestic arbitration proceedings on the basis of a subjective element. It provides that certain rights may only be exercised by parties which are neither of Belgian nationality nor residents in Belgium. ${ }^{94}$

The UNCITRAL Model Law defines 'internationality' much more broadly. It considers an arbitration 'international' whenever one of the alternatively listed objective and subjective internationality requirements are met. ${ }^{95}$ Article 1 para. 3 of the UNCITRAL Model Law provides:

An arbitration is international if:

(a) the parties to an arbitration agreement have, at the time of the conclusion of that agreement, their places of business in different States; or

(b) one of the following places is situated outside the State in which the parties have their places of business:

(i) the place of arbitration if determined in, or pursuant to, the arbitration agreement;

(ii) any place where a substantial part of the obligations of the commercial relationship is to be performed or the place with which the subject-matter of the dispute is most closely connected; or

(c) the parties have expressly agreed that the subject matter of the arbitration agreement relates to more than one country. ${ }^{96}$

Here again, it becomes obvious that the drafters of the UNCITRAL Model Law sought to ensure its broad application. Legislators in some jurisdictions have even gone a step further and implemented the UNCITRAL Model Law without any distinction between international and domestic arbitration proceedings at all. ${ }^{97}$ In these jurisdictions, the benefits of a harmonized arbitration law are available for domestic and international arbitrations alike.

94 Art. 1718 Belgian Judicial Code, which reads: 'By an explicit declaration in the arbitration agreement or by a later agreement, the parties may exclude any application for the setting aside of an arbitral award, where none of them is a natural person of Belgian nationality or a natural person having his domicile or normal residence in Belgium or a legal person having its registered office, its main place of business or a branch office in Belgium.' For a similar approach in other jurisdictions see, e.g., Vibroflotation AG v Express Builders Co Ltd. [1994] 3 HKC 263, finding that an international arbitration was given because plaintiff and defendant had their places of business in different States. See also Cairo Regional Center for International Commercial Arbitration, No. 1/1994, Egypt, 31 October 1995, UN Doc. A/CN.9/ SER.C/Abstracts/75 at 8.

${ }_{95}$ Bantekas, supra n. 10, 21. On the interpretation of these criteria see, e.g., Vanol Far East Marketing Pte Ltd v Hin Leong Trading (Pte) Ltd [1996], Singapore High Court ('SGHC') 108.

96 Art. 1 (3) UNCITRAL Model Law.

${ }_{97}$ The 10th Book of the German Code of Civil Procedure, for example, generally applies to international and domestic arbitration proceedings alike. An exception 
An element of internationality may also be required for the application of international conventions on arbitration. As set forth in Chapter 10, the New York Convention applies to the recognition and enforcement of arbitral awards rendered at a place of arbitration other than the State where recognition and enforcement is sought.$^{98}$ Hence, it is the foreign place of arbitration (rather than the nationality, residence or domicile of the parties) that defines internationality. States may also declare that they apply the Convention to awards that are non-domestic. Under this alternative, it is not the place of arbitration but the international nature of the relationship that triggers the obligation to recognize and enforce arbitral awards. ${ }^{99}$

The above survey shows that various instruments apply different definitions of internationality. ${ }^{100}$ While some instruments define international by reference to the parties, others refer to the place of arbitration, the subject-matter of the dispute or a combination of the aforementioned criteria. An arbitration that is considered international under one particular lex arbitri does not necessarily qualify as international under a different lex arbitri or under a convention such as the New York Convention, and vice versa.

only applies for the recognition and enforcement of arbitral awards. In this respect, German law refers to the standards of the New York Convention for the recognition and enforcement of foreign arbitral awards. For the enforcement of domestic arbitral awards, in contrast, German law refers to the standard applicable to set-aside applications. See Sections 1060 et seq. German Code of Civil Procedure.

98 Art. I New York Convention.

99 For example, Section 202 United States Federal Arbitration Act defines the arbitration agreements that fall under the New York Convention in the following way: 'An agreement or award arising out of such a relationship which is entirely between citizens of the United States shall be deemed not to fall under the Convention unless that relationship involves property located abroad, envisages performance or enforcement abroad, or has some other reasonable relation with one or more foreign states.'

100 See also Blackaby et al., supra n. 67, 9; Lew et al., supra n. 3, 58. 